\title{
Late-Pleistocene paleohydrography, eolian activity and frozen ground, New Jersey Pine Barrens, eastern USA
}

\author{
H. French ${ }^{1, *}$ \& M. Demitroff ${ }^{2}$
}

1 Departments of Geography and Earth Sciences, University of Ottawa, Ottawa, 0N, Canada.

2 Department of Geography, University of Delaware, Newark, DE, USA.

* Corresponding author. Email: hmfrench@shaw.ca.

Manuscript received: November 2011, accepted: May 2012

\begin{abstract}
The Late Pleistocene surface paleohydrography of the New Jersey Pine Barrens consisted of a series of broad braided alluvial surfaces with meandering paleochannels. This drainage is best explained in terms of impermeable (i.e. frozen) substrate, high sediment load, variable or decreasing discharge, and eolian sedimentary dynamics. Evidence for eolian activity is provided by wind-abraded sand grains, coversand, dunes, ventifacts, deflation hollows and wind-polished boulders. In several places stream avulsion occurred due to channel infilling by locally-derived wind-blown sediment. The braided and meandering river systems that characterise the tundra and polar semi-desert lowlands of the Western Canadian Arctic are described as modern analogs.
\end{abstract}

Keywords: Paleodrainage, eolian activity, stream avulsion, frozen ground, Late Pleistocene, New Jersey Pine Barrens, Arctic Canada

\section{Introduction}

The dynamics of changing fluvial processes in response to fluctuating climatic conditions has been a major element of many studies aimed at Pleistocene paleoenvironmental reconstruction. This has certainly been the case for the lowlands of western and central Europe (e.g. Starkel, 2000, 2003; Vandenberghe, 1995, 2001, 2002, 2008; Vandenberghe \& Woo, 2002) where the change from temperate to cold and then back to temperate conditions resulted in marked changes in surface hydrology and frozen ground conditions.

In this article we summarise some of the evidence that suggests the Late Pleistocene surface drainage of the Mid Atlantic Coastal Plain of eastern North America was characterised by nival-generated fluvial runoff regimes, frozen ground conditions and strong eolian activity. We concentrate upon the Pine Barrens of southern New Jersey, a region characterised by low-elevation upland surfaces separated by broad poorlydrained depressions and river valleys.

\section{Background}

Following detailed field surveys, W.L. Newell (Newell, 2005; Newell et al., 1989, 1995, 2000, 4-5) concluded that relict coldclimate landforms and sediments can be found in southern New Jersey. Earlier studies with J.S. Wycloff concerned the surface hydrology of the area (Newell \& Wycloff, 1992). They had concluded that current fluvial processes were largely ineffective in modifying the present landscape and further suggested (p. 27-28) that the broad shallow valleys in which drainage is concentrated indicate at least an order of magnitude increase in discharge that could only have been possible when runoff occurred over impermeable (frozen) ground. The latter was subsequently confirmed by the present authors (French and Demitroff, 2001; French et al., 2003, 2005, 2007) who have documented the widespread occurrence of frost fissures and thaw-related structures in the Pine Barrens of southern New Jersey. It is now clear that the entire coastal plain of southern New Jersey and adjacent areas of northern Maryland experienced extended periods of either permafrost or deep seasonal frost during the Late Pleistocene (French et al., 2009; Newell \& De Jong, 2011). 


\section{Late Quaternary history}

During the cold periods of the Late-Pleistocene, southern New Jersey was located approximately $50-150 \mathrm{~km}$ south of the glacial limits (Fig. 1). Strong sustained winds, both katabatic from the ice sheet and those associated with the zonal westerlies, would have dominated areas proximal to the ice margins (Markevich et al, 2009). During these times, vegetation on the relatively well-drained sandy and gravelly terrain of the Pine Barrens was restricted to non-arboreal species; the area would have possessed either tundra-like or shrub-tundra vegetation. Deflation would have been widespread and the poorlyvegetated floodplains and upland surfaces would have supplied local sediment for wind transport and abrasion.

Stratigraphic investigations conducted since 2001, and more recent electromagnetic induction (EMI) and three-dimensional ground-penetrating radar (GPR) imaging (Demitroff, 2010), enable construction of a Late Quaternary chronology for the Pine Barrens. We have also utilised the early air photo coverage of southern New Jersey, flown for the State of New Jersey between 1930 and 1932. This was a time when lumbering and deforestation was extensive, the present Pine Barrens forests had not become reestablished, and widespread commercial agriculture had not commenced. As a consequence, these photographs provide aerial views of the Pine Barrens terrain that cannot be replicated by modern remote sensing.

The typical Late Pleistocene and Holocene stratigraphy (Fig. 2) can be inferred from two generations of relict sand wedges that penetrate Miocene-age sand and gravel and which formed on a Late Pleistocene paleo-surface characterised by a fragipan. The sediment within the wedges indicates that permafrost conditions existed during Marine Isotope Stages (MIS) 4 and 2. A thaw-related structure (a 'sediment-filled pot'; see French et al., 2005) was luminescence dated by its eoliansand fill to MIS 3 and indicates a climatic amelioration at that time. The Late Pleistocene-Holocene transition is represented by an overlying layer of coversand and colluvium. Wind-faceted pebbles are commonly found beneath the Holocene colluviums and above the Miocene paleo-surface.

\section{Evidence for strong wind action}

The morphological and sedimentological evidence that indicates strong wind action during the Late Pleistocene in the Pine Barrens is briefly summarised here.

Fig. 1. The Mid-Atlantic Coastal Plain and the New Jersey Pine Barrens. a. Map of surficial deposits and landscape elements of the Mid-Atlantic Coastal Plain. The area that includes the New Jersey Pine Barrens is indicated. The southern limit of Pleistocene-age permafrost is indicated. Modified from Newell \& De Jong, 2011; b. Map showing extent of the New Jersey Pineland National Reserve; this area is commonly termed the Pine Barrens.

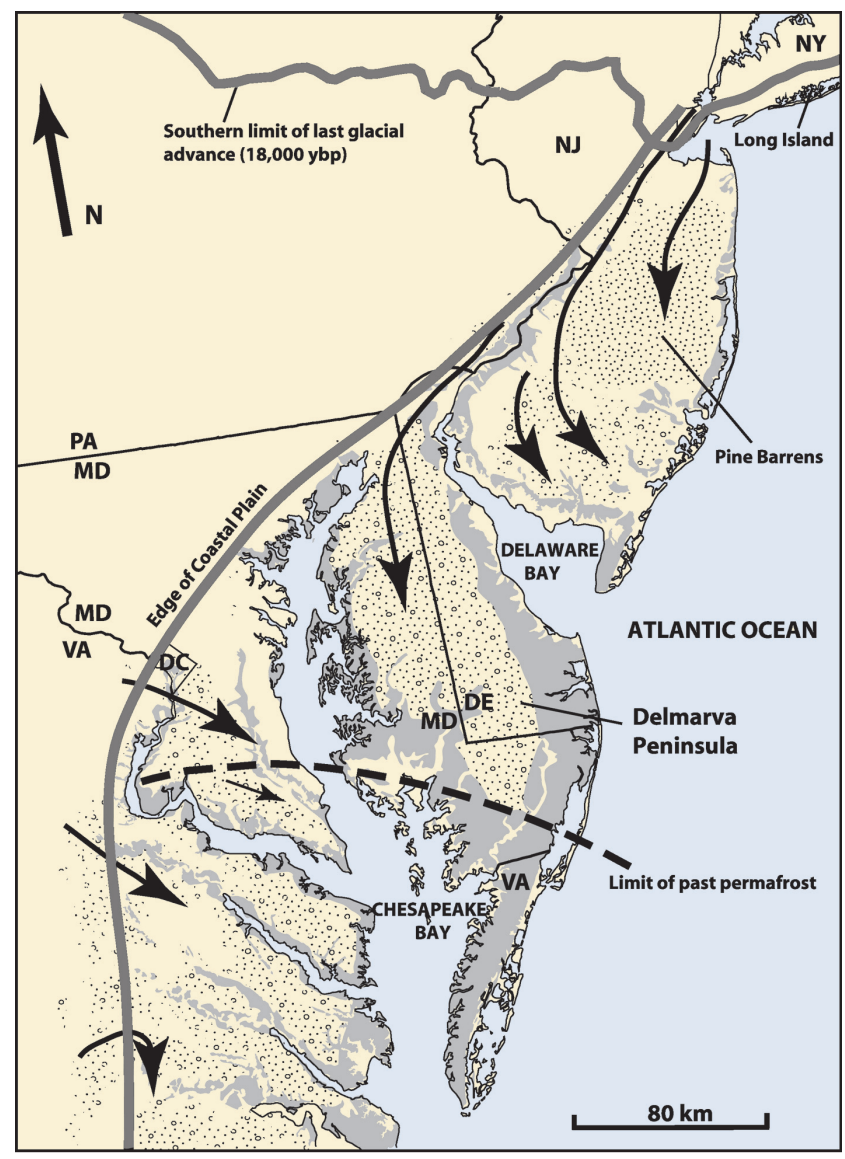

Upland surface developed on oldest Miocene fluvial-marine deltaic deposits (area of Pine Barrens)

Upland surface developed on deeply weathered Miocene-Pliocene upland gravel

Terraces underlain by Pleistocene marine high-stand coastal and estuarine deposits

Paleotransport directions

$a$

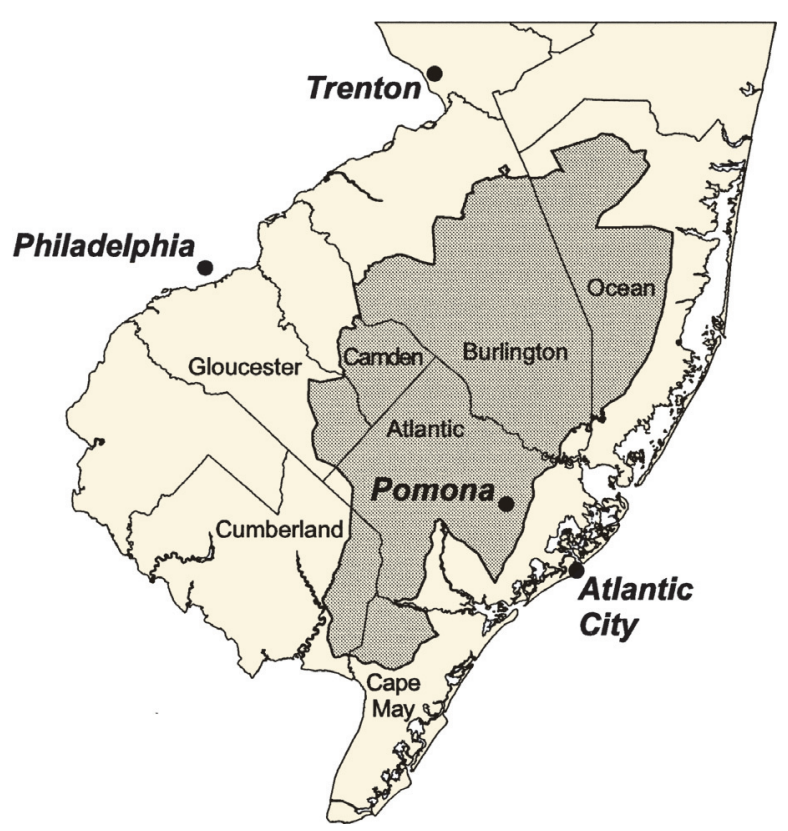

b. 


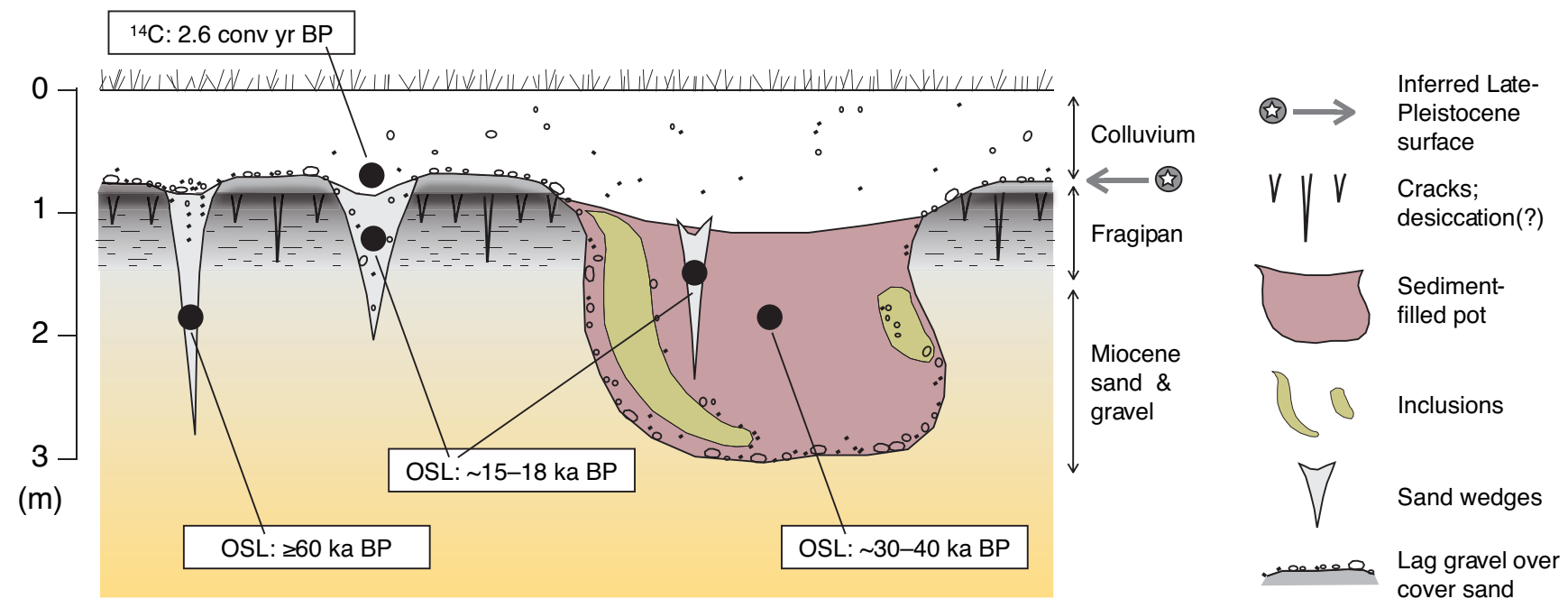

Fig. 2. A sketch that shows the typical Late Pleistocene and Holocene stratigraphy of southern New Jersey. Periglacial features include MIS-4 and MIS-2 frost cracks, a MIS-3 thaw-related structure ('sediment-filled pot'), fissures (desiccation?) in a fragipan layer capped by windblown sand, and Holocene colluvium. Figure modified from French et al, 2007.

\section{Wind-abraded Sand Grains}

Using a modified Cailleux method, J. Gozdzik (University of Lodz, Poland) examined samples of the sand that veneers the Pine Barrens surface (see French et al., 2003, 262-265). The typical morphology is that more than $60 \%$ show extreme roundness (Fig. 3a). This compares with only approximately $20 \%$ in the underlying sandy gravels of the underlying substrate that show a similar extreme roundness. For example, Fig. 3b shows a typical non-wind-abraded sand grain that characterises the substrate. Some of the wind-abraded sands have been OSL dated to MIS 4 or MIS 6 (i.e. more than $60 \mathrm{ka} \mathrm{BP}$ ) (see Fig. 2), others are of Holocene age. In general, the older the sand deposition, the greater has been the degree of wind abrasion.

\section{Ventifacts, wind-polished boulders and rock coatings}

Pebble- to cobble-sized ventifacts occur widely in the Pine Barrens (Fig. 3c). Wind faceting is most pronounced on the well-rounded constituents of channel-bar residuum found on the upland plateaus. They assume a variety of shapes; so-called 'einkante', 'dreikanter' and 'brazil-nut' shapes can all be found. Generally, these ventifacts provide convincing evidence that upland surfaces have been little altered since the end of Younger Dryas times. However, it is not possible to infer paleowind directions because most have moved either by gravity processes or human disturbance following early colonial forest clearance and subsequent agriculture.

Silcrete and ironstone boulders (Fig. 3d) that occur on hilltops and within the colluvium that mantles upper valley side slopes (Wyckoff \& Newell, 1992; Newell et al., 2000) also show signs of wind abrasion and polishing (French \& Demitroff, 2003, 127-130). Some are characterised by a silica glaze (see Fig. 3d). Preliminary results from photomicrographs of the rock coatings on ironstone boulders indicate that three distinct layers occur: 1) a heavy metal oxide skin, 2) a silica glaze; and 3) a mix of silica glaze and iron oxide film (R. Dorn, pers. comm., 2010). The genesis of such rock coatings is unclear and several explanations have been suggested. For example, in extremely cold and arid regions, like Antarctica, analyses suggest a chemical or biochemical origin, perhaps added by wind (e.g. Campbell and Claridge, 1987, 124129; Dorn and Oberlander, 1982; Dorn et al, 1992). In the Pine Barrens, the entrainment of dust particles within wind-blown ice crystals might have aided the accretion of rock coatings.

\section{Deflation Hollows}

French and Demitroff (2001) interpret the numerous enclosed wetlands and depressions ('spungs') that characterise the New Jersey Pine Barrens as having formed as deflation hollows during the Late Pleistocene and early Holocene. Basin morphology can frequently be explained by the relationship between landscape position and soil moisture dynamics. For example, on higher elevations and well-drained upland surfaces, depressions possess a typical parabolic, or blowout, profile. In contrast, those adjacent to rivers are not parabolic because they developed commonly in poorly-drained sediments situated near, or at, the water table, thereby hindering wind scour.

\section{Coversand and Dunes}

Sand veneers much of New Jersey's Outer Coastal Plain and silty loess-like deposits blanket the Inner Coastal Plain. According to Newell et al. (2000), the wind-blown sediments of the Inner Coastal Plain are of Pleistocene to possibly early Holocene age, and were derived from exposed terraces in the Delaware River valley. 

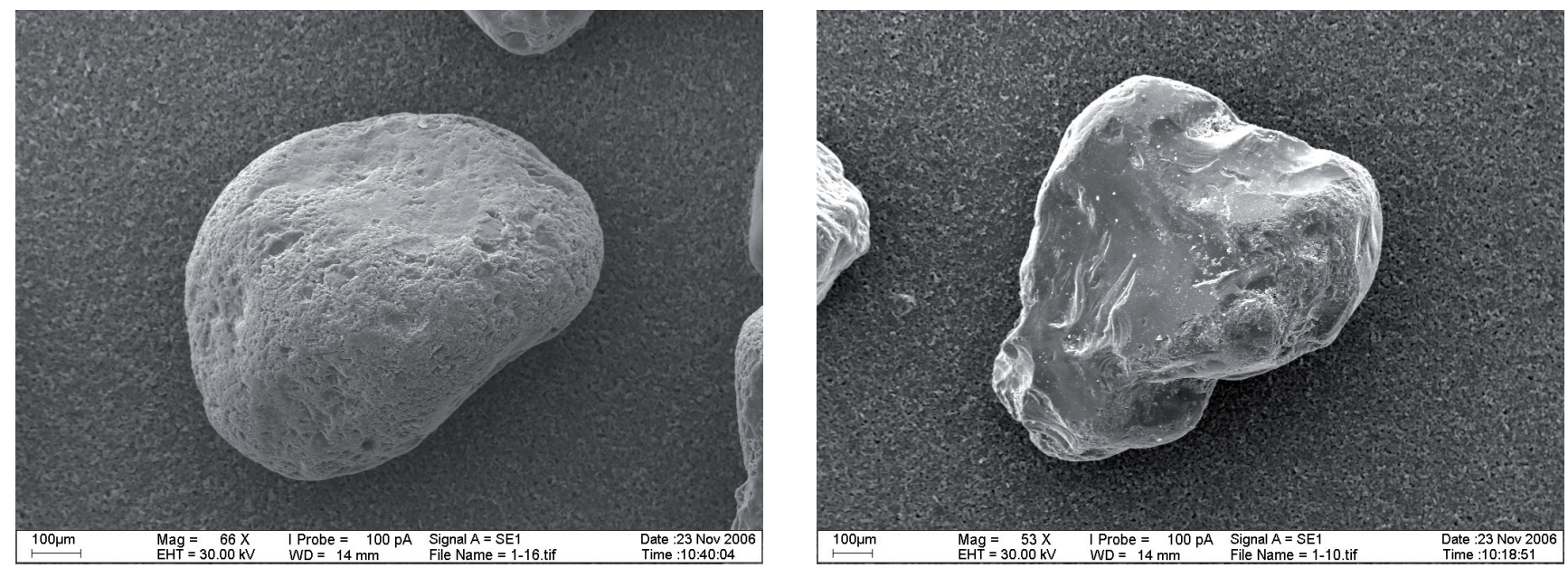

a.

b.
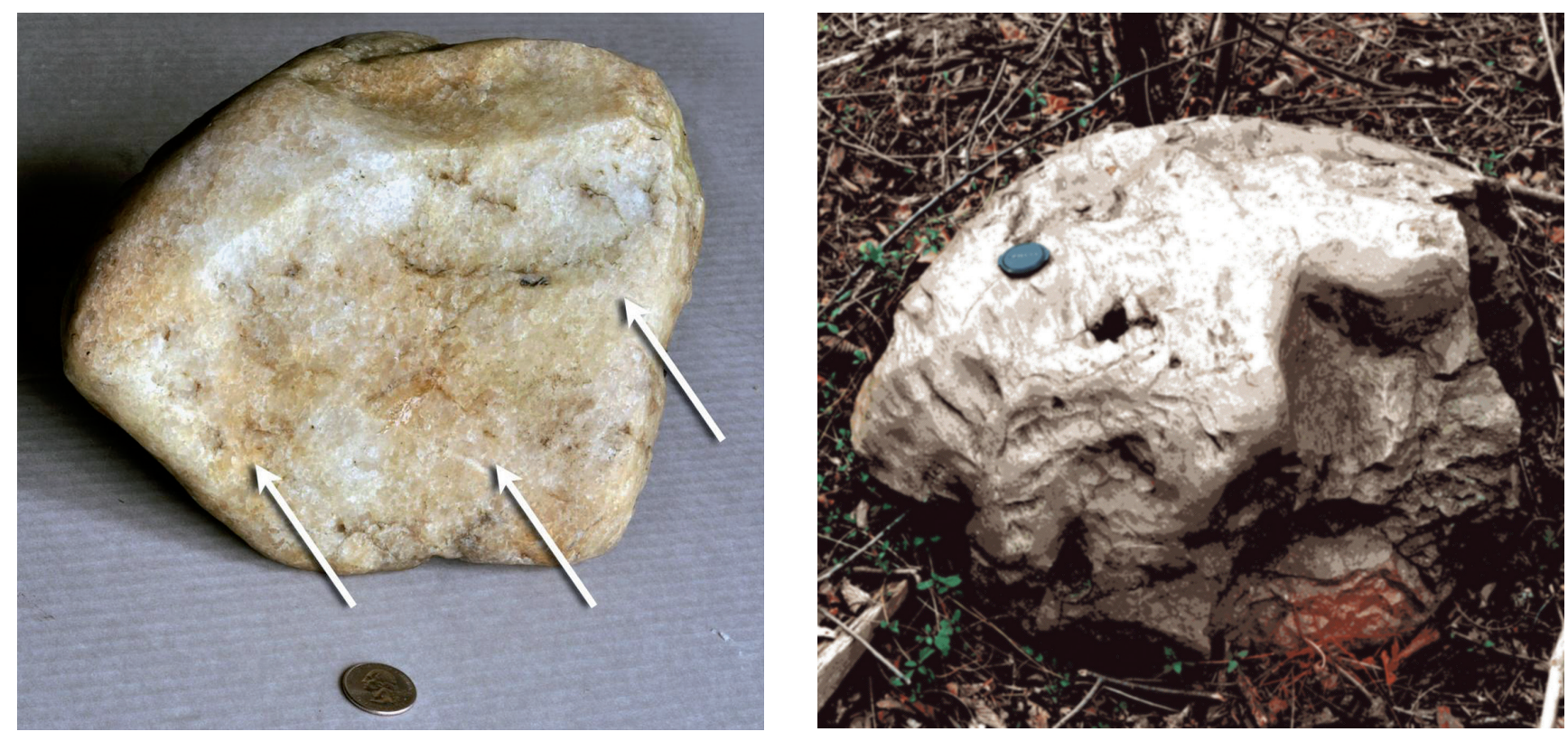

d.

Fig. 3. Evidence of Late Pleistocene and Early Holocene wind action in the Pine Barrens. a. SEM photo (mag. $\times 66)$ of a near-surface wind-abraded sand grain; b. SEM photo (mag. $\times 53$ ) of a non-wind-abraded sand grain from underlying Bridgeton Formation sand and gravel; c. a coarse grained quartzitic ventifact on upland surface of the Pine Barrens, scale provided by coin, arrows indicate wind abraded facet and inferred wind direction; $d$. a large silcrete ('cuesta quartzite') boulder showing wind scalloping and polishing, scale is given by $6 \mathrm{~cm}$ diameter camera lens cap.

Subtle dune and dune-like landforms are present in the Pine Barrens. Today, they are not easy to discern because they are masked by the forest cover. The sand veneer is commonly 0.5 to $2.0 \mathrm{~m}$ thick and the sand particles do not possess the same degree of abrasion as that found within relict sand-wedges. The most pronounced dunes are sand patches that occur along the southern and eastern banks of river and stream channels. Deposits are narrow in width $(<0.5 \mathrm{~km}$ wide) suggestive of hairpin parabolic dunes. The direction of wind transport is suggested by the northwest to southeast orientation of the dunes. Luminescence dating indicates that sand transport ended just after the Younger Dryas; the youngest luminescence date obtained so far is $11.26 \pm 1.14 \mathrm{ka}$ (USU-269) at $0.5 \mathrm{~m}$ depth atop a fluvio-eolian channel fill.

\section{Pine Barrens hydrology}

The uplands of the New Jersey Pine Barrens form a plateau, 30-60 m high, which dips gently eastwards towards the Atlantic 0cean. The topographic divide separating these uplands from the Delaware River valley to the west is created by outcropping of the Kirkwood Formation of Miocene age (Newell et al., 2000). This formation consists of gently dipping, fine-grained quartzitic sand with occasional silt and clayey beds. The formation locally exceeds $30-40 \mathrm{~m}$ in thickness. The Kirkwood Formation is overlain by $\sim 10-20 \mathrm{~m}$ of quartz-rich sand and sandy gravel of the Cohansey Formation and then by a capping, of variable thickness, of silty clay, arkosic sandy gravel and cobbles that is assigned to the Bridgeton Formation. Both the Cohansey and 
Bridgeton Formations are of late Miocene age and they also dip towards the east. According to Newell et al., $(2000,3)$ the Cohansey is highly permeable and forms a vast recharge area for a shallow ground-water aquifer system centered on the underlying Kirkwood Formation. This aquifer constitutes an important major potential groundwater resource for the large urban areas that surround the Pine Barrens.

The main drainage systems (Fig. 4) are incised within the Bridgeton Formation. The valleys are characterised by broad swampy bottoms that are commonly 10-25 m below the upland surfaces and between 1 and $3 \mathrm{~km}$ wide. The Maurice River flows south to enter Delaware Bay and the Great Egg Harbor and Mullica Rivers flow southeast towards the Atlantic 0cean. Only the Rancocas Creek and its tributaries flow westward into the Delaware River. In many places, the valley bottoms are cut into the underlying Cohansey Formation.

Discharge records (U.S. Geological Survey, 1979-1986) for these four watersheds indicates that stream flow is almost entirely groundwater-flow driven, equaling about $89 \%$ of the region's annual runoff. Base flow is relatively uniform throughout the year. During extreme precipitation events, there is little overland flow because of the high permeability of the substrate. According to Newell \& Wycoff $(1992,25)$ sediment yield for the entire region is small, probably averaging 10-40 tons/mile ${ }^{2}$. In summary, today's streams are misfit, low-energy systems that flow in broad, poorly-defined valleys.
Across the broad lowlands of the Pine Barrens, the surface underlain by coversand appears to possess no coherent surface drainage. Wetlands are widespread, infiltration rates are high and the groundwater table appears to fluctuate both seasonally and on an annual basis. A common complaint from local residents and concerned environmentalists is that the wetlands are drying up and the area is 'losing water'. These observations merely confirm the highly permeable nature of the Miocene substrate, especially the sand of the Cohansey Formation which underlies the Pine Barrens.

Demitroff (2007) has documented the close relationships that exist between subtle terrain characteristics and drainage in the Pine Barrens. Local words describe these relationships. For example, enclosed shallow depressions that form wetlands or intermittent pools are called 'spungs', short intermittent drainages are called 'cripples', and small ponds fed by perennial springs are called 'blue holes'. The last commonly occur adjacent to the main channels or, occasionally, on the broad alluvial surfaces that border the watercourses. Typically, marked changes in channel morphology occur at blue-hole sites; upstream, the valleys are broad and flat with one or more indistinct channels, downstream, the channels are better defined, clearly reflecting the more uniform discharge regime.

In summary, groundwater discharge from the sandy and gravelly substrate generally defines the channel and flood plain morphology of the modern surface water hydrology.

Fig. 4. Map showing the main surface drainage systems of southern New Jersey, isopachs of the Kirkwood-Cohansey aquifer system and location of USGS discharge monitoring stations, 1979-1986. The area described in detail in the present paper centers upon the catchment of the Great Egg Harbor River. Map reproduced from Newell \& Wycoff, 1992, figure 7.1 .

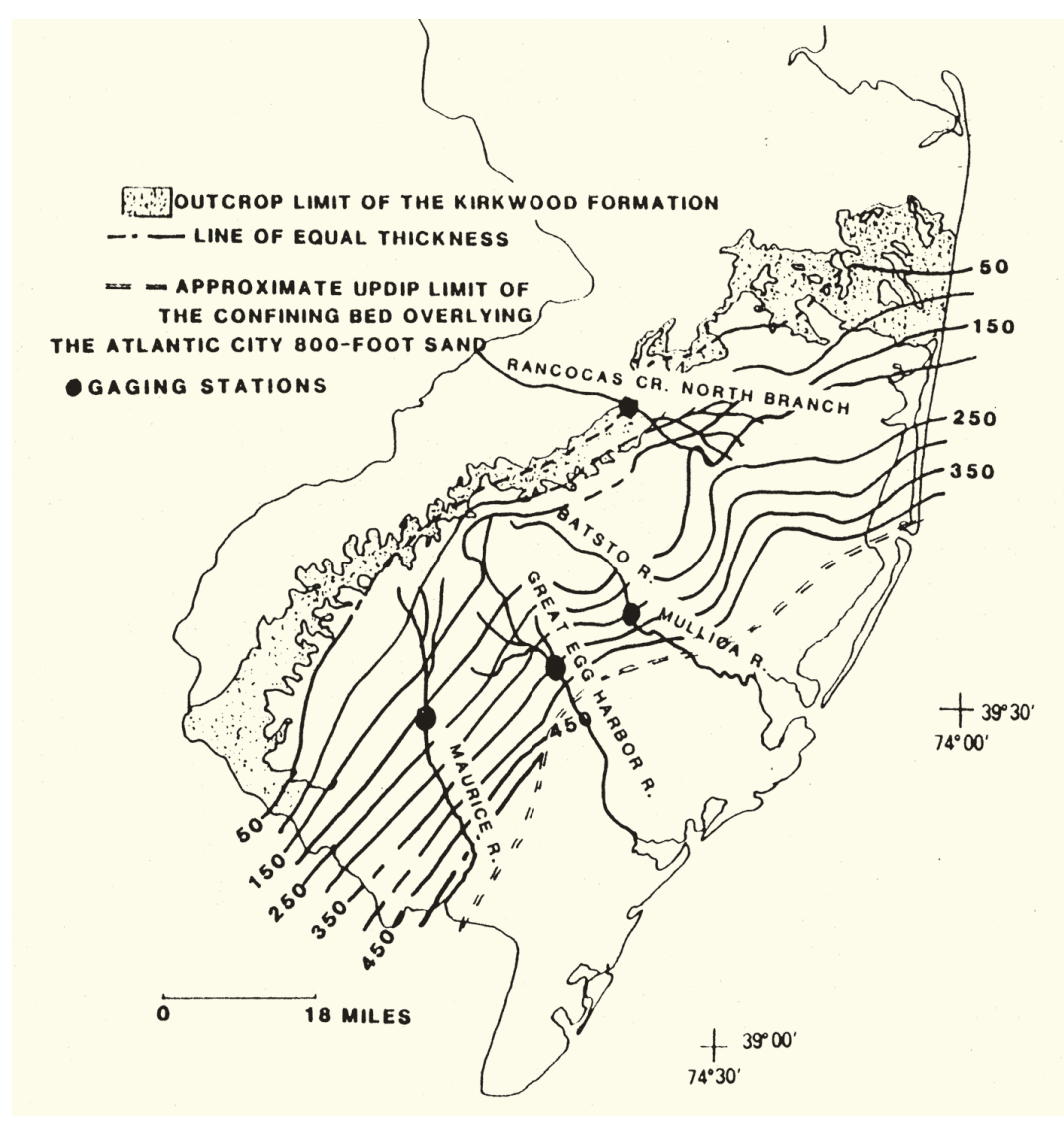




\section{Paleohydrography and modern cold-climate analogs}

Low altitude aerial photography of the Pine Barrens was flown for the State of New Jersey in the early 1930's (NJ Department of Environmental Protection, 1931). This was at the end of a time period that lasted two centuries during which the timber resources of southern New Jersey had been exploited to provide fuel for iron smelting and other economic purposes. By 1930, the forest cover had largely disappeared. The black-andwhite tonal contrasts on the mosaics (see Fig. 5) indicate subtle drainage and soil textural differences that are no longer visible on modern air photographs due to reforestation, urbanisation, or commercial agriculture. These photographs provide a unique opportunity to identify the Late Pleistocene-early Holocene paleo-surface drainage of the Pine Barrens. They confirm the earlier suggestion that significant surface runoff occurred when the ground surface was frozen and when the region experienced strong, sustained eolian activity.
Figure 5 reproduces the 1931 aerial photomosaic sheet of the area near Hammonton, Atlantic County. This sheet is typical of the 1931-1932 coverage of the Pine Barrens and is used here to illustrate the connection between paleohydrography and Late Pleistocene-early Holocene wind action.

The upper right corner of Fig. 5 covers part of the watershed of the current Great Egg Harbor River where a number of beaded or cuspate paleo-tributaries coalesce into a single channel. The tonal contrasts in the photograph clearly pick out the Holocene swamp deposits, subsequently mapped by Newell \& Wycloff (1992), that now infill the former channel (Fig. 6a). Large alluvial fans grade from an upland surface underlain by Bridgeton Formation gravel. The direction of inferred sediment transport is indicated by arrows. The rest of Fig. 5 illustrates the typical terrain of the Pine Barrens uplands; numerous spungs and cripples are visible, and light-colored NW-SE oriented streaks indicate reworking of the sand veneer into shallow hairpin parabolic dunes (Demitroff, 2007, 2008).

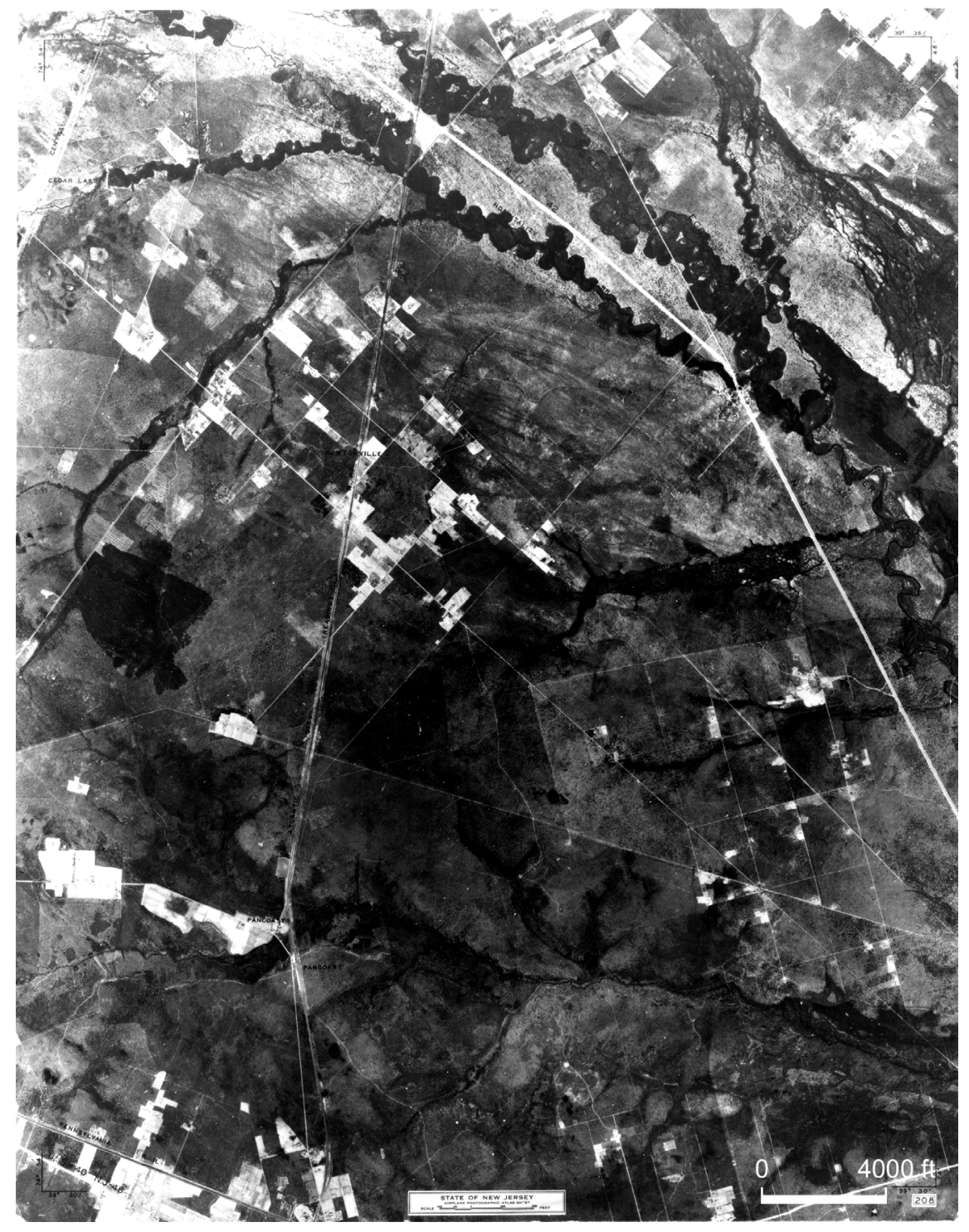

Fig. 5. Reproduction of the 1931 aerial photomosaic sheet for the area near Hammonton, northern Atlantic County, that was published by the State of New Jersey. The modern State Highway \#322 follows the old highway closely and is seen to cross diagonally the upper right corner of the sheet. The upper right quarter of the frame shows paleobraided channels of the Great Egg Harbor River and its associated Penny Pot and Hospitality Branch tributaries. It also shows the beaded, or 'cuspate', pattern of the valley bottoms in which the present streams flow. 


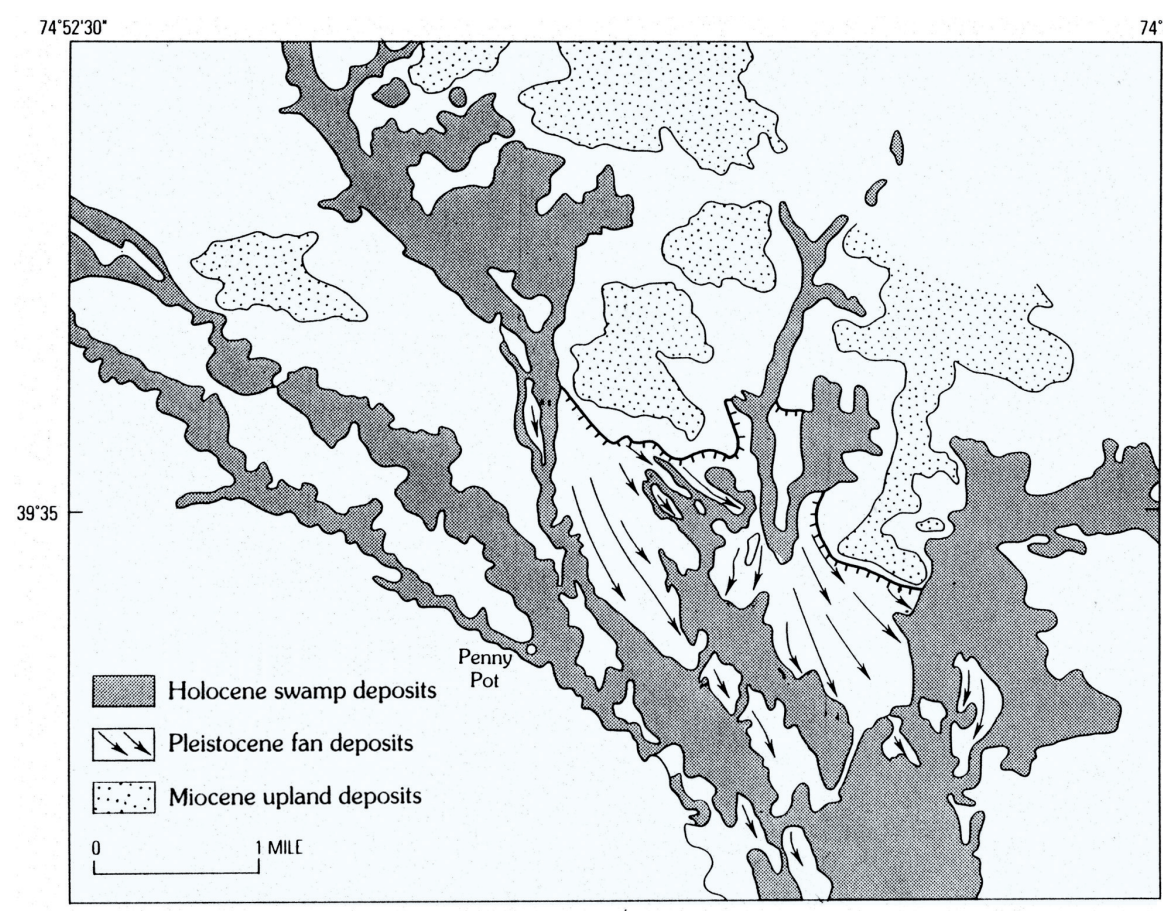

a.

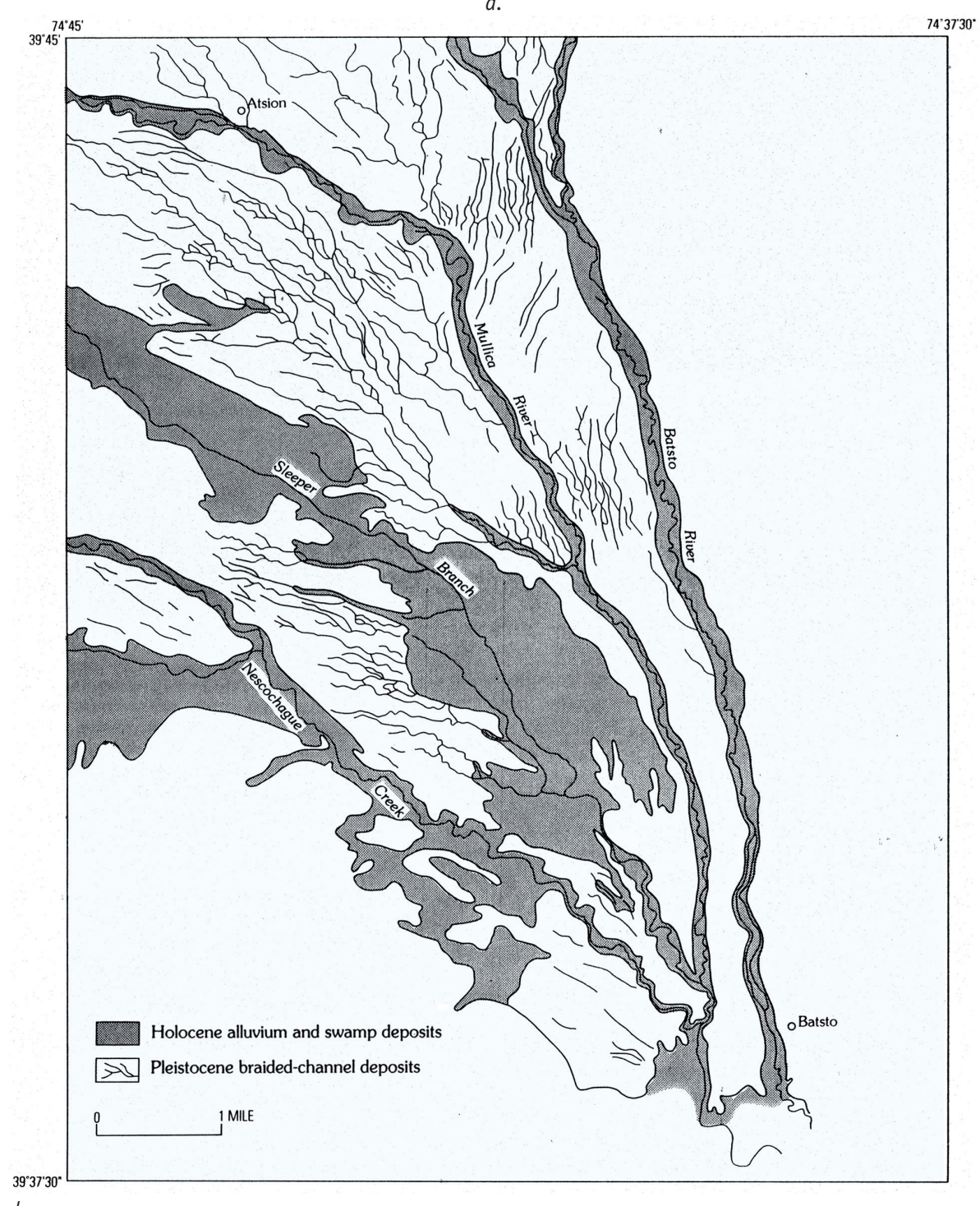

Fig. 6. Examples of the surficial deposits and geomorphology associated with the paleodrainage systems in southern New Jersey identified by Newell and Wycloff (1992, figures 7.3 and 7.3). a. Part of the Great Egg Harbor River Valley north of Penny Pot that is covered in the upper right corner of Fig. 5. The hachured line marks the boundary between the uplands underlain by Bridgeton Formation of Miocene age and the Pleistocene alluvial fan deposits; $b$. Part of the Mullica River Valley north of Batso, Atlantic and Burlington Counties.

The Holocene drainage is incised within the Pleistocene braided channel deposits. Both diagrams are reproduced from Newell \& Wycloff, 1992. 


\section{Braided and Meandering Paleochannels}

Many photomosaic sheets reveal that the upper reaches of today's streams (e.g. Mullica, Maurice, Manumuskin, Mantantico, etc.) flow within broad shallow braided paleo-channels (Newell \& Wyckoff, 1992). Sedimentological studies support this interpretation (Farrell et al., 1985). One example mapped by Newell and Wycloff (1992) (Fig. 6b) shows the Late Pleistocene braided channels and alluvial fans of the Mullica River where the Holocene meandering drainage is incised within earlier braid plain stream deposits.

Many photomosaics also reveal that paleochannel meanders typically occur in association with adjacent eolian bedforms. One example is the relict dunes adjacent to the meanders in the paleo-catchment of the Great Egg Harbor River (see Fig. 6a). Similar phenomena occur in the paleo-Maurice River catchment.

According to Vandenberghe $(2001,114)$, meanders in coldbased rivers are often related to transient and modest energy systems. It is also generally accepted that a combination of increased sediment load and decreasing discharge favor a braided rather than a meandering pattern. But in the case of the Pine Barrens, several site-specific controls may also have applied. For example, substrate permeability would have been reduced due to the presence of frozen ground. On the other hand, where a stream transgressed an area of oriented hairpin dunes, eolian deposition would have occurred within the channel and in areas where a stream progressively incised itself into underlying Cohansey Formation sand, increased infiltration into this highly permeable substrate would probably have occurred. Thus, while frozen ground would have increased the effectiveness of surface runoff, increases in sediment load and decreases in discharge would have favored the adoption of a braided pattern.

\section{Paleochannels and Stream Avulsion}

Several examples of ancient stream avulsion due to channel infilling by eolian sediment can also be recognised on the aerial photomosaics. They occur in areas where local sand reservoirs are present. For example, Figure 6a shows a series of sand corrugations (parabolic or hairpin dunes) over a kilometre in width that extend for about seven km along the right bank of the paleo Great Egg Harbor River Valley. At one locality, a soil boring atop a dune crest indicated loose, friable single-grain sand to a depth of $3.25 \mathrm{~m}$. The dune arms run nearly parallel to the main river channel. The dune-blocking of several smaller stream channels debouching from the south is readily apparent. At one locality, dunes completely blocked the paleochannel (Fig. 7). Sand at a depth of $1.0 \mathrm{~m}$ within this channel has been luminescence dated to $28.16 \pm 2.80 \mathrm{ka}$ (USU-267), a time period that coincides with regional permafrost thaw (see French et al., 2007).
A second example of paleochannel avulsion is inferred from recent data obtained at the C-17 Assault-Landing Runway, Joint Air Base McGuire-Dix-Lakehurst (Demitroff 2010). There, EMIimaging revealed an ancient channel filled with sand and with only a slight swale to mark its former location. A sample of the sand taken at a depth of $0.5 \mathrm{~m}$ was luminescence dated to $11.26 \pm 1.14 \mathrm{ka}$ (USU-269). This indicates channel avulsion occurred prior to that time.

\section{Modern Analogs}

The paleohydrography of the Pine Barrens appears remarkably similar to the current surface hydrology that can be observed today on the perennially-frozen lowland terrain of the western Canadian High Arctic islands. There, much of western Banks Island, western Prince Patrick Island, and parts of Meighen, Ellef Ringnes, Borden and Brock Islands are underlain by gravel and sand of the Beaufort Formation, of late Miocene-early Pliocene age (Tozer and Thorsteinsson, 1964; Thorsteinsson and Tozer, 1962). Elsewhere in the Queen Elizabeth Islands, and especially in central part of Banks Island, large areas are underlain by weakly consolidated sandstone of the upper unit of the Eureka Sound Formation, of early Tertiary age (Tozer and Thorsteinsson, 1964; Miall, 1979). These lithologies are very similar to that of the Pine Barrens substrate.

Two examples illustrate the typical surface hydrology that exists on western Banks Island, Canada (Fig. 8). The first is tundra terrain underlain by sand of the Eureka Sound Formation; the second is polar semi-desert terrain underlain by sand of the Beaufort Formation.

\section{a. The tundra lowlands of central and western Banks Island}

(Fig. 8a)

Gently rolling hills, shallow valleys and alluvial flats and benches characterise the central lowlands of Banks Island. Relative relief varies between 10 and $100 \mathrm{~m}$. The region is drained by a series of long, west-flowing rivers, the lower parts of which are strikingly braided while the upstream portions are partly braided and partly meandering. The adjacent upland areas, thinly veneered by either Quaternary or Beaufort Formation sediments (Vincent, 1983), are also dissected by a series of shallow abandoned braided river channels that expose underlying sand of the Eureka Sound Formation (Miall, 1979). Figure 8a shows part of the central Bernard River system where it is joined by a major tributary from the north. The distinctive nature of the Bernard River is that that it consists of a meandering main channel within a broader, braided, channel system.

\section{b. The Beaufort Plain, northwest Banks Island (Fig. 8b)}

The Beaufort Plain consists of a gently-sloping surface that rises from sea level at the west coast to an altitude of $\sim 250 \mathrm{~m}$ inland. The Beaufort Formation itself consists of the unlithified 


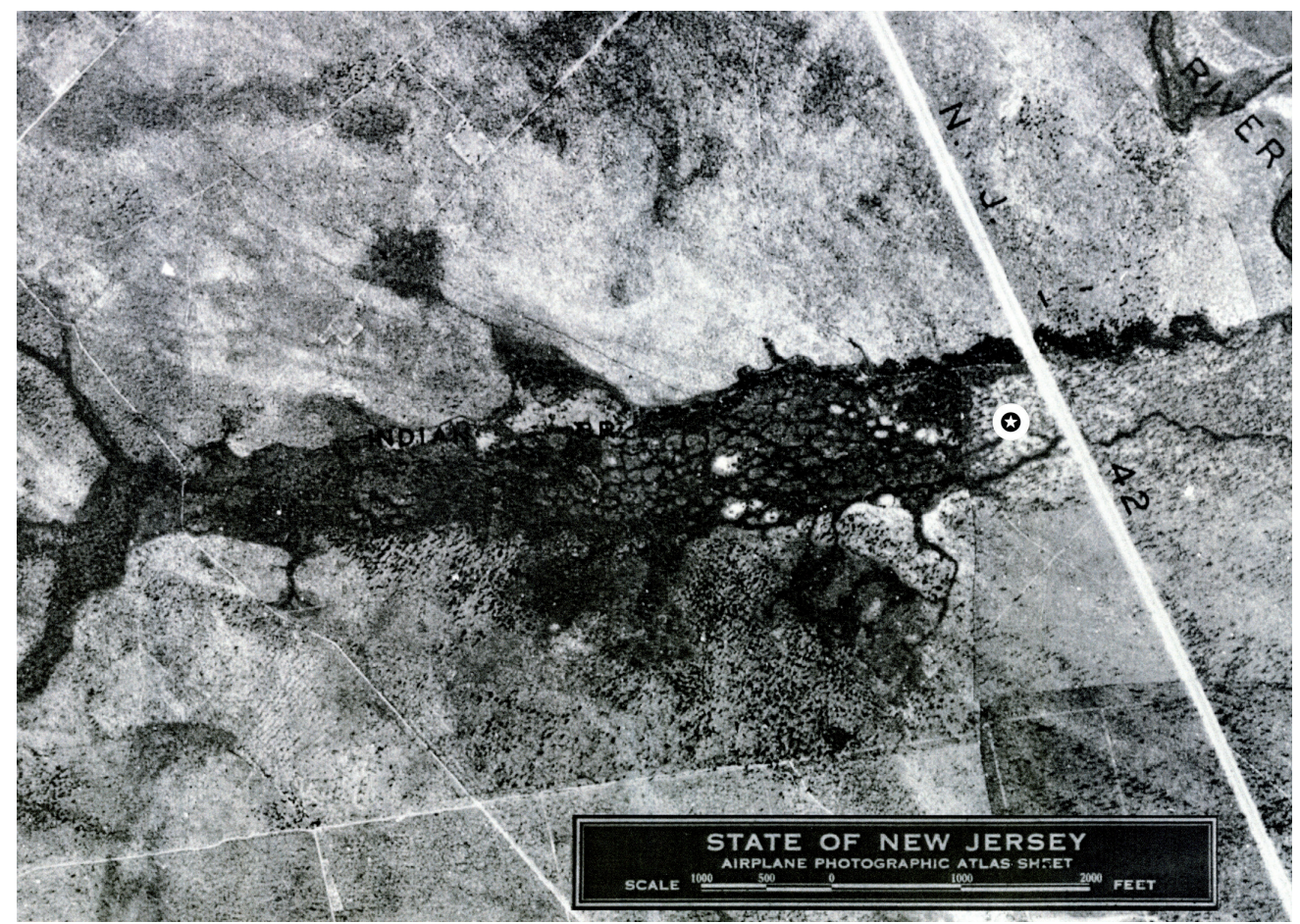

Fig. 7. A 1931 airphotomosaic that shows part of the Indian Branch tributary of the Great Egg Harbor River north of Weymouth, Atlantic County (see also Fig. 5). The modern New Jersey Highway \#322 closely follows the old NJ Highway 42. Stream avulsion is inferred by the fact that the lower (right) part of the channel that is crossed by NJ Highway 42 is filled with sand that is OSLdated at $28 \mathrm{ka}$. The upper part of the channel contains poorly drained organic sediments that possess a distinct orthogonalrectilinear pattern that suggests the former existence of icy permafrost (thermal contraction cracking). Pit and sample location is indicated by the star.

sandy deposits of braided rivers and is probably Pliocene in age (Fyles, 1990). Vegetation is extremely sparse and the plain is best regarded as a polar semi-desert. The surface is drained by a series of west-flowing streams that occupy shallow asymmetrical valleys that are typically incised to depths of 10-40 m (French, 1971). In their lower reaches however, as shown in Fig. $8 b$, the rivers become strikingly braided and towards the coast, the drainage systems coalesce to form extensive, poorly-drained alluvial and deltaic surfaces highly reminiscent of the paleodrainage of the Pine Barrens (see Fig. 5).

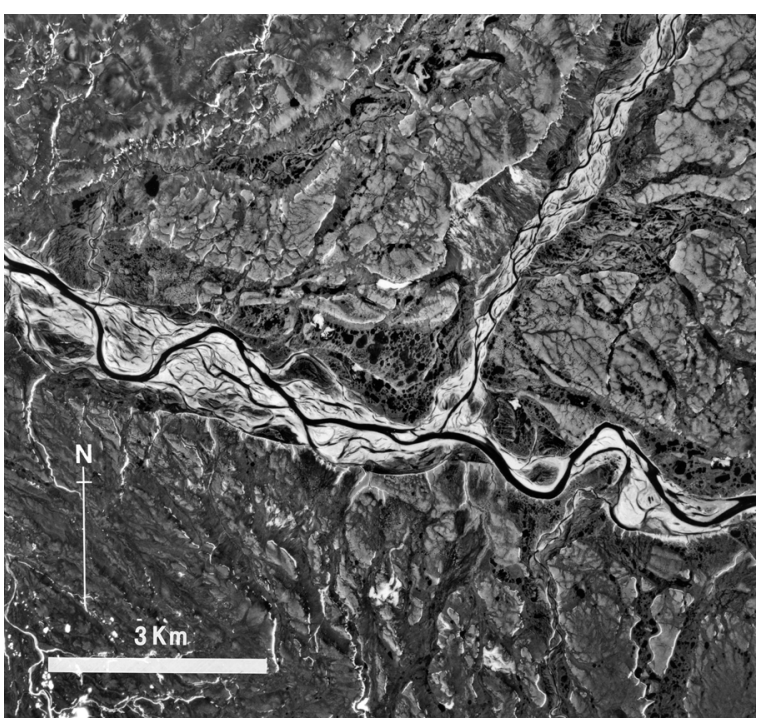

a.

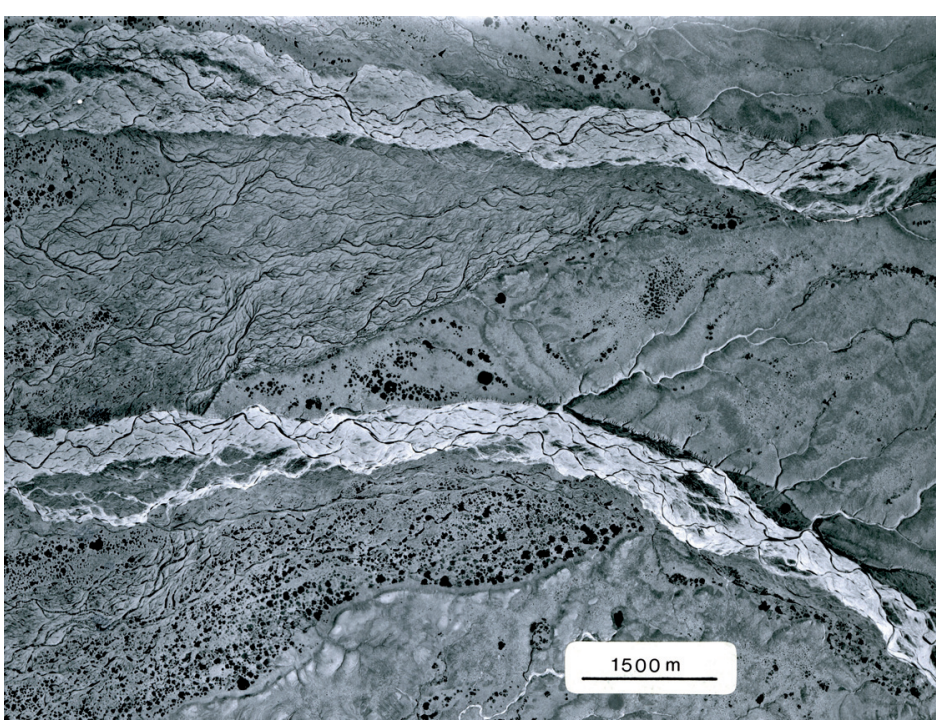

$b$.

Fig. 8. Modern analogs. The extensive lowlands of many of the Western Canadian High Arctic Islands are underlain by perennially-frozen, poorlyconsolidated sandy and gravelly sediments of Late Tertiary age. These lithologies are similar in nature to those that underlie the New Jersey Pine Barrens. a. The lowlands of central and western Banks Island. This vertical air photo (part of NAPL photo A17564-48) shows the current meandering main channel of the Bernard River flowing within a broader braided channel. Abandoned paleo-channels and more recent low-level alluvial terraces are also present; b. The Beaufort Plain of northwestern Banks Island. This vertical air photo (part of NAPL photo A17381-77) shows two of the rivers that originate on the upland surface to the east and then drain westward to the coast where the braided channel systems coalesce to form poorly-drained deltaic and alluvial plains. Both photos are from the National Air Photo Library (NAPL), Ottawa; copyright, The Queen of Canada. 


\section{Conclusions}

Abraded sand grains, ventifacts, wind-abraded boulders, rock coatings, and an eolian sand cover suggest that the Pine Barrens experienced strong wind action on several occasions during the Late Quaternary. Aerial photomosaics taken in 1931-1932 when the forest cover was largely absent reveal a well developed Late Pleistocene surface paleodrainage system. An explanation invoking previously-frozen ground best explains why the normally porous and permeable sediments of the Pine Barrens were able to support surface drainage. Conditions of permafrost or deep seasonal frost probably prevailed. The broad braided paleochannels and alluvial fans suggest a nival-dominated discharge regime similar to that which currently exists in the Canadian High Arctic. In places, eolian sand deposition caused drainage avulsion. Age determinations indicate that eolian activity continued into the Holocene.

\section{Acknowledgements}

Comments by W. L. Newell and two anonymous reviewers are much appreciated by adoption.

\section{References}

Campbell, I.B. \& Claridge, G.G.C., 1987. Antarctic: Soils, Weathering, processes and Environments. Elsevier (Amsterdam), 386p.

Demitroff, M., 2007-2008. The Newtonville dune field. New Jersey Audubon, Fall/Winter 2007-08: 32-33.

Demitroff, M., 2007. Pine Barrens wetlands: geographical reflections of South Jersey's periglacial legacy. MSc Thesis, Department of Geography, University of Delaware (Newark), Delaware, USA.

Demitroff, M., 2010. Lakehurst Soil Study. Preliminary Review of Magnetic Lineations - C-17 Assault-Landing Runway, Joint Air Base McGuire-DixLakehurst, NJ: Potential Environmental Significance. Internal Report, Buckhorn Garden Service, Inc. (Vineland), New Jersey, 61 pp.

Dorn, R. \& Oberlander, T.M., 1982. Rock varnish. Progress in Physical Geography, 6: 317-367.

Dorn, R., Krinsley, D.H., Lin, T., Anderson, S., Clark, J., Cahill, T.A. \& Gill, T.E., 1992. Manganese rich rock varnish does occur in Antarctica. Chemical Geology, 99: 289-299.

Farrell, S.C., and others, 1985. Pleistocene? braided stream deposits in the Atsion Quadrangle area, northwestern Atlantic County, New Jersey. In: Talkington, R.W. (ed.): Geological investigations of the Coastal Plain of Southern New Jersey, Field guide, Second Annual Meeting of the Geological Association of New Jersey, Stockton College, Pomona, New Jersey: New Jersey Geological Association (New Brunswick): pA-1 to A-11.

French, H.M., 1971. Slope asymmetry of the Beaufort Plain, northwest Banks Island, NWT, Canada. Canadian Journal of Earth Sciences, 8: 717-731.

French, H.M. \& Demitroff M., 2001. Cold-climate origin of the enclosed depressions and wetlands ('spungs') of the Pine Barrens, southern New Jersey, USA. Permafrost and Periglacial Processes, 12: 337-350.
French, H.M. \& Demitroff, M., 2003. Late Pleistocene periglacial phenomena in the Pine Barrens of southern New Jersey: Field excursion guide, October 11, 2003. In: Hosik, \& M. Mihalasky, M. (eds): Proceedings, Geological Association of New Jersey, $20^{\text {th }}$ Annual Meeting. Richard Stockton College (Ponoma), New Jersey: 117-142.

French, H.M., Demitroff, M. \& Forman, S.L., 2003. Evidence for late-Pleistocene permafrost in the New Jersey Pine Barrens (latitude $39^{\circ} \mathrm{N}$ ), eastern USA. Permafrost and Periglacial Processes, 14: 259-274.

French, H.M., Demitroff, M. \& Forman, S.L., 2005. Evidence for Late-Pleistocene thermokarst in the New Jersey Pine Barrens (latitude $39^{\circ} \mathrm{N}$ ), eastern USA. Permafrost and Periglacial Processes, 16: 173-186.

French, H.M., Demitroff, M., Forman, S.L. \& Newell, W.L., 2007. A Chronology of Late-Pleistocene permafrost events in southern New Jersey, eastern USA. Permafrost and Periglacial Processes, 18: 49-59.

French, H.M., Demitroff, M. \& Newell, W.L., 2009. Past permafrost on the MidAtlantic Coastal Plain, Eastern United States. Permafrost and Periglacial Processes, 20: 285-294.

Fyles, J.G., 1990. Beaufort Formation (Late Tertiary) as seen from Prince Patrick Island, Arctic Canada. Arctic, 43: 393-403.

Markewich, H.W., Litwin, R.J., Pavich, M.J. \& Brook, G.A., 2009, Late Pleistocene aeolian features in southeastern Maryland and Chesapeake Bay region indicate strong WNW-NW winds accompanied growth of the Laurentide Ice Sheet. Quaternary Research, 71: 409-425.

Miall, A.D., 1979. Mesozoic and Tertiary geology of Banks Island, Arctic Canada. Geological Survey of Canada, Memoir, 387, 235 p.

New Jersey Department of Environmental Protection, 1931. Airplane atlas sheets, aerial photomosaics. Bureau of Tidelands, Trenton, New Jersey, 261 sheets, scale $1: 100,000$.

Newell, W.L., 2005. Evidence of cold-climate slope processes from the New Jersey Coastal Plain; debris flow stratigraphy at Haines Corner, Camden County, New Jersey. United States Geological Survey, Open File Report 2005-1298. http://pubs.usgs.gov/of/2005/1296.

Newell, W.L. \& Clark, I., 2008. Geomorphic Map of Worcester County, Maryland, Interpreted from a LIDAR-Based Digital Elevation Model. United States Geological Survey, Open File Report 2008-1005. http://pubs.usgs.gov/of/2005/1005.

Newell, W.L. \& De Jong, B.D., 2011. Cold-climate slope deposits and landscape modifications of the Mid-Atlantic Coastal Plain, Eastern USA. In: Martini, I.P., French, H.M. \& Perez Alberti, A. (eds): Ice-marginal and periglacial processes and sediments. Geological Society of London, Special Publication 354: 259-276.

Newell, W.L. \& Wycloff, J.S., 1992. Paleohydrology of four watersheds in the New Jersey Coastal Plain. In: Gohn, G.S. (ed.): Proceedings, 1988 US Geological Survey workshop on the geology and geohydrology of the Atlantic Coastal Plain. United States Geological Survey, Circular 1059: 23-28.

Newell, W.L., Wyckoff, J.S., Owens, J.P. \& Farnsworth, J., 1989. Southeast Friends of the Pleistocene, $2^{\text {nd }}$ annual field conference: Cenozoic geology and geomorphology of southern New Jersey Coastal Plain, November 11-13, 1988. United States Geological Survey, Open File Report 89-159.

Newell, W.L., Powars, D.S., Owens, J.P. \& Schindler, J.S., 1995. Surficial geologic map of New Jersey, southern sheet. United States Geological Survey, Open File Report 95-272, scale $1: 100,000$.

Newell, W.L., Powars, D.S, Owens, J.P., Stanford, S.D. \& Stone, B.D., 2000. Surficial geologic map of central and southern New Jersey. United States Geological Survey, Miscellaneous Investigations Series, Map 1-2540-D. 
Starkel, L., 2000. Chronology of phases of various fluvial activity, erosion and deposition in the Vistula catchment during Late Quaternary. Geochronometria, 19: 53-58.

Starkel, L., 2003. Palaeohydrology of Central Europe. In: Gregory, K.J. \& Benito, G. (eds): Understanding global change, John Wiley and Sons Ltd: 87-103.

Thorsteinsson, R. \& Tozer, E.T., 1962. Banks, Victoria and Stefansson Islands, Arctic Archipelago. Geological Survey of Canada, Memoir, 330, 85p.

Tozer, E.T. \& Thorsteinsson, R., 1964. Western Queen Elizabeth Islands, Arctic Archipelago. Geological Survey of Canada, Memoir 332, 242p.

Vandenberghe, J., 1995. Timescales, climate and river development. Quaternary Science Reviews, 14: 631-638.

Vandenberghe, J., 2001. A typology of Pleistocene cold-based rivers. Quaternary International, 79: 111-121.

Vandenberghe, J., 2002. The relation between climate and river processes, landforms and deposits during the Quaternary. Quaternary International, 91: 17-23.

Vandenberghe, J., 2008. The fluvial cycle at cold-warm-cold transitions in lowland regions: A refinement of theory. Geomorphology, 98: 275-284.

Vandenberghe, J. \& Woo, $\boldsymbol{M}-K_{\text {. }}, 2002$. Modern and ancient periglacial river types. Progress in Physical Geography, 26: 479-506.

Vincent, J-S., 1983. La géologie du Quaternaire et la géomorphologie de L'ile Banks, Arctique Canadien. Commission Géologique du Canada, Mémoire, 404, 118 p.

Wycoff, J.S. \& Newell, W.L., 1992. Silcrete near Woodstown, New Jersey. In: Gohn, G.S. (ed.): Proceedings, 1988 U.S Geological Survey workshop on the geology and geohydrology of the Atlantic Coastal Plain. United States Geological Survey, Circular 1059: 39-43. 